\title{
EXCHANGE OF TECHNICAL INFORMATION
}

\begin{abstract}
HE Defence Contracts Bill, which received its second reading in the House of Commons and was committed to a Standing Committee on December 12, 1957, is concerned primarily, as the President of the Board of Trade, Sir David Eccles, explained in opening the debate, with the use in defence contracts of technical information which is not the subject of a patent or registered design. Its main object is to revoke certain emergency powers at present possessed by the Government and to sub. stitute limited but permanent powers enabling such technical information, which may be the product of much experiment and development work, to be used for defence purposes. These existing powers are possessed by the Government under the Patents Act, 1946, and the Registered Designs Act, and for this reason, and because the Board of Trade is responsible generally for questions of industrial property, the Bill was sponsored by the President of
\end{abstract} the Board of Trade.

The Bill is the second attempt made since 1951 to revise the law dealing with the use of patented inventions and registered designs for the services of the Crown. The Inventions and Designs (Crown Uses) Bill introduced into the House of Lords in December 1953 permanently empowered Government Departments to authorize the "use" and "disclosure" of technical information for "the services of the Crown". These powers were strongly opposed in the second reading debate, Lord Rochdale pointing out that under its terms anybody could be compelled to disclose information not only to a Government servant but also to a third party, possibly one of his competitors, who might then publish what he had learnt. The Bill was withdrawn, and as a result of discussions between Government Departments and industry, a small committee was appointed, with Sir Harold Howitt as chairman, to inquire into the desirability of any such permanent powers and the conditions under which, if necessary, they should be exercised.

The Committee reported in June 1956 and the new Bill, which is intended to remove the grounds for complaint voiced by Lord Rochdale, is based on the recommendations of the report. The Committee received evidence that industry now relies to an increasing degree on detailed information, such as working drawings, models, designs, technical records, and details of workshop practice, which is either unpatentable or is not in practice patented. Such technical information is frequently exchanged between firms under agreements which provide, apart from payments, for maintenance of secrecy and for restrictions on the use of the information by the recipient in the interest of the supplier or licensor. The preservation of secrecy is important since such information may be the result of many years of research, development and trial, but only after considerable reflexion did the Howitt Committee conclude that the balance of argument was in favour of the Government being given permanent powers in place of the present Defence Regulations issued during the Second World War, which enabled contracting Departments to authorize the use of such information for defence and other purposes.
Nevertheless, the Howitt Committee recommends the full maintenance of the secrecy provisions of existing agreements : there should be no power whatever to require "disclosure" as distinct from "use", and the powers should be limited to defence requirements, which should be narrowly defined. Before these powers are exercised the parties concerned should be given three months to negotiate new agreements, and only if these negotiations fail to produce results deemed satisfactory by the Government should the Government have power to override any term of the agreement. Such power, moreover, should only be exercised after consideration of each individual case at a high level, and any person adversely affected should have the right of fair and just compensation and of appeal to a judge of the High Court, sitting, if requested by the parties, with two assessors agreed by the parties or appointed by the Lord Chancellor.

The Committee believes that these proposals ensure that an overseas manufacturer, having developed a technique which he regards as of great value to himself, should have no reason to fear that it might be divulged to some third party as a result of the exercise of Government powers. Incidentally, the Committee directs attention in this report to the need to clarify the Section 27 (1) of the Patents Act, 1949 , which purports to deal with technical information relating to patented inventions. It should be made clear, it suggests, either that this section was intended to deal with technical information relating to patented invention, there being some special reason why it should be dealt with separately in that way, or that the section was inadvertently enacted in wider terms than was intended or contemplated, in which event amending legislation would be appropriate.

The Defence Contracts Bill terminates the current period of emergency in which additional powers to use patented inventions and registered designs are conferred on the Crown under the Patents Act, 1949, and the Registered Designs Act, 1949, and makes it clear that statutory provision for the use of models, documents and information does not authorize disclosure to the Government or any other person in contravention of any contractual restriction. Clause 2 of the Bill makes permanent provision for the use by Government contractors, for the production of defonce materials, of technical information in their possession which is protected by contractual arrangements, subject to the safeguards recommended in the Howitt report. The term 'defence materials' is interpreted to cover, first, articles designed or adapted for the use of the Armed Forces of the Crown, or for supply to allied countries for their defence, and components of such articles; secondly, articles designed or adapted for civil defence purposes, and their components; and thirdly, articles required for the production, repair or maintenance of such articles.

This definition of defence materials follows the recommendation of the Howitt Committee; but obviously could lead to difficulties in the case of supplies of defence materials to allied countries. It was on this point that a rather unsatisfactory debate 
seemed to concentrate and also on the limitation of the Bill to the defence services. Sir Frank Soskice, and also other Opposition speakers, while concerned at the implications for industry of the Bill as regards the supply of defence materials to allied countries, ignored the assurance of the Howitt Committee on this point. On the other hand, he sought to extend the scope of the Bill to cover contracts for other services of the Crown, especially the health services. The trend of his remarks regarding the disclosure of technical information are indeed disturbing. It would be most unfortunate if industry came to rely excessively upon secrecy rather than upon patents, even if the patent law were more unsuited to the needs of British industry to-day than appears to be the case.

In a recent article on this subject in the Journal of Industrial Economics $(5,157$; 1957), Mr. C. A. Bloxam expressed the opinion that the patent system is the only one so far devised which reconciles the encouragement of technological innovation by commercial interests with encouragement to make available to the public the maximum amount of information regarding such innovations. Mr. Bloxam's inquiry has satisfied him that it also offers effective safeguards to prevent the use of patents for suppressing inventions; indeed, a particularly interesting part of Mr. Bloxam's article is that in which he presents reasons for believing that patents are not suitable instruments for suppressing invention. The article is worth noting in this connexion as setting the issues raised by the Bill in the context of those which determine the rate of application of science and technology in industry, particularly in view of the comparatively sterile debate referred to; the latter makes desirable a more objective discussion such as is to be found in the report on industry and technical progress prepared for the Science and Industry Committee of the Royal Society of Arts, the British Association and the Nuffield Foundation.

Sir Frank Soskice did not suggest that information should be disclosed to rivals, but he appeared to take a remarkably optimistic view as to the safety of information disclosed to Government departments, an optimism that is unlikely to be shared by the overseas manufacturer whom the Howitt Committee rightly had in mind. There is a question of confidence here which is particularly important if British industry is to take the fullest advantage of the opportunities for development to which Mr. J. H. Dunning has directed attention. Furthermore, this question of technical information is particularly important in regard to research and development in pharmaceuticals, which would appear to be one aspect of the health services that Sir Frank Soskice had in mind.

Mr. W. R. Rees-Davies, in supporting the Bill, was much more practical. He recognized that it might be necessary to widen the powers of the Bill later; but he held that the experience gained under the present Bill would give a much clearer idea of the practical difficulties and how best to handle the question of private contracts. Sir David Eccles, in replying on the debate, was emphatic that at present overseas manufacturers would be unwilling to enter into agreements involving the supply of technical information to British firms, if the Government possessed the wider powers which the Opposition sought to write into the Bill.

The problem is undoubtedly difficult, and the debate failed to give weight to some of the factors to which the Howitt Committee directed attention. It is, in fact, intimately related to the vital question of Anglo-American co-operation. Britain benefits greatly, as the Howitt Committee observed, throughout the whole economy, from the use of the knowledge developed particularly in the United States; and currency difficulties, geographical propinquity and sentimental ties all lead Commonwealth and Western European countries to turn more readily to the United Kingdom than to the United States. Anything which checked this interchange of information, or discouraged the practice of some American companies of allowing their British associates to exploit in Britain and elsewhere the techniques which they have developed, would have serious repercussions on the British economy. It is to be hoped that this wider issue will be more fully and objectively discussed in the subsequent proceedings in Parliament.

\section{TECHNICAL STUDENTS IN BRITAIN}

TN speaking at a residential course for teachers in schools and technical colleges at St. Annes-onSea on January 21, Mr. A. A. Part, Under-Secretary in charge of the Further Education Branch at the Ministry of Education, said that the Minister had asked the Central Advisory Council for Education to make a special inquiry into the wastage of students in some of the main part-time courses in technical colleges. The inquiry was needed to provide more evidence from which the facts could be studied and, after referring to figures recently quoted by Lady Gertrude Williams and Dr. G. B. Frisby, director of the Nationel Institute of Industrial Psychology, Mr. Part said that even without a special inquiry it could be seen that more practicable courses like the new course in mechanical engineering craft practice were required. It was also necessary to re-emphasize the relatively high standard of the National Certificate, and that this, even in its first three years up to Ordinary National Certificate, was designed for future technicians and technologists and was suitable only for those craft apprentices with an academic background above average and who showed strong promise of being able to rise out of the ranks of craftsmen. The really substantial wastage occurred at the beginning of the course, and available evidence suggested that very few of those who failed at the end of the first year of the course ultimately obtained an Ordinary National Certificate. Mr. Part believed that too many students were being admitted either with inadequate ability in mathematics or with too narrow an academic background, or both.

Mr. Part said that the weakness of many of the present arrangements lay in the inadequate standards of entry required by some colleges ; the rigidity of some apprenticeship schemes, or their inflexible local interpretation; the often unsuccessful interpolation of several terms at an evening institute between leaving school and starting a National Certificate course; and the temptation to some schools to narrow studies in the last year so as to concentrate on the three subjects normally required for the examination 